\title{
A-Na(d) tayaSati \\ Hubungan Anapanasati (Nafas Buddha) di dalam Struktur Tari Klasik Thailand
}

Oleh

\section{Potchanan Pantham}

\section{Universitas Srinakharinwirot, Bangkok, Thailand}

pampotchanan@gmail.com

\section{RINGKASAN}

A-Na(d)tayaSati adalah penciptaan karya tari dengan menyatukan prinsip hubungan Anapanasati (napas Buddha) dengan struktur gerak tari klasik Thailand. Tujuan penciptaan agar bisa mengarah pada salah satu bentuk atau metode gerakan tari Thailand yang berfokus pada penggunaan napas sebagai landasan struktur gerakan independen, alami, dengan mengambil kekuatan energi dari dalam ke luar. Hal ini untuk membuat gerakan tersebut bertahan lama sehingga bisa bergerak dalam jangka waktu yang lebih lama, dan merupakan gerak yang tenang melalui meditasi yang alami, tanpa memaksa tubuh. Karya ini bertujuan pula untuk menciptakan gerakan lain dalam tarian Thailand yang konsisten dengan doktrin Buddha, yang sadar akan jangkauannya saat ini dan alami melalui latihan dan kesadaran diri. Dengan menerapkan prinsipprinsip meditasi dalam bentuk Anapanasati dan teori gerakan tubuh sesuai dengan (teori Pemrograman Motor) dalam anatomi untuk menemukan hubungan dari gerakan tari klasik Thailand yang memberikan arti penting bagi gerakan dengan napas penari.

Proses penciptaan hubungan Anapanasati (Napas Buddha) dengan struktur gerak tari klasik Thailand, sebagai pengakuan adanya gerakan baru yang memiliki energi aerobik (Aerobic system) yang beredar sepanjang waktu. Hal ini merupakan sistem tubuh yang menggunakan oksigen untuk membakar sepenuhnya dan terbentuk sebagai energi yang berkelanjutan dan damai dari dalam tubuh yang disebabkan oleh meditasi dengan metode pernapasan sambil melalukan gerakan tari klasik Thailand. Selain itu, tubuh tetap memiliki postur yang jelas, kuat dan unik dengan struktur gerakan tari klasik Thailand namun menjadi lebih ringan, lebih nyaman dan lebih alami. Energi dari 


\section{JOGED}

ISSN: $1858-3989$
Potchanan Pantham A-Na(d) tayaSati Hubungan Anapanasati (Nafas Buddha) di dalam Struktur Tari Klasik Thailand

napas masuk dan ke luar itu membuat gerakan menjadi terus-menerus, tanpa akhir, tanpa masalah kelelahan dan kontraksi otot saat bergerak ketika menari.

Kata Kunci: Gerakan tubuh, Tari klasik Thailand, Anapanasati, Meditasi

\section{ABSTRACT}

The dance work creation with the principle of the relationship of Anapanasati (Buddha's breath) in the structure of the classical Thai dance movement. In the aim of being able to lead to one form or method of Thai dance movements that focuses on the use of breath as a foundation for the structure of independent movements, natural, and take energy from the inside to outside. This makes the movement very durable so that it can move for a longer period of time and is a quiet movement through natural meditation, without force. To create another movement in Thai dance that is consistent with Buddhist doctrine, which is aware of its current and natural reach through practice and self-awareness. By applying the principles of meditation in the form of Anapanasati and the theory of appropriate body movements (Motor Programming theory) in anatomy to find the connection of classical dance movements Thailand which gives importance mean to movement with the breath of dancers.

The process of creating Anapanasati (Buddha's Breath) with the mobement structure of the Thai classical dance as recognition of a new movement that has an aerobic system circulating around the time. This is a body system that uses oxygen to burn completely and is formed as a continuous and peaceful energy from the inside caused by meditation with the breathing method while moving the Thai classical dance movement. Besides that, the body still has a clear and strong posture that is unique with the structure of Thai classical dance movements such as lighter, more comfortable and more natural. The energy of in and out breath makes the movement become continuous, endless, without a problem of fatigue and muscle contraction during movements in the dance.

Keywords: Body movements, Thai classical dance, Anapanasati, Meditation 


\section{PENDAHULUAN}

Beberapa gerakan manusia berasal dari penghasil pola gerak rhythmic pattern generator) sebuah sirkuit yang memiliki tautan dengan sirkuit kompleks di sumsum tulang belakang atau otak. Teori pemprograman gerak (Motor Programing Theory) adalah gerakan yang diproduksi oleh penghasil pola gerak yang merupakan gerakan berirama yakni pola gerak berulang seperti pernapasan. Menurut teori ini, gerakan dapat terjadi dari penghasil pola irama (rhythmic pattern generator) tanpa kerja otak dan tidak memerlukan stimulus dan sirkuit sensorik (Rumpa dan Prayod Boonsinsuk, 2004: 61) bukan seperti gerakangerakan yang lain.

Gerak tari klasik Thailand dikendalikan oleh bagian belakang otak yang disebut "Cerebullem" yang berfungsi menjaga keseimbangan tubuh untuk menghasilkan gerakan anggun yang khas dan unik dari pertunjukan tari Thailand sejak masa lalu sampai sekarang. Gerakan tari klasik Thailand mempertimbangkan keseimbangan tubuh, memiliki efek menahan pinggul dan menjaga berat tubuh pada saat melakukan gerakan. Karena alasan ini, tari klasik Thailand dicirikan oleh gerakan yang lambat, lembut, dan tenang yang harus selalu dilakukan seimbang supaya gerakan tampak anggun (Somporn Furaj, 2011:71).

Menurut Pichet Klunchun, seorang seniman Khon Thai kontemporer, struktur tari Thailand dipusatkan di tubuh bagian tengah. Para penari akan mengumpulkan energi di sekitar mereka dan mengirimkannya ke lingkaran pusat ini. Dengan demikian, tari Thailand memiliki energi yang bergerak masuk dan ke luar dalam lingkaran dan terhubung secara terstruktur (Parichat Jaingwiwattanapron, 2006: 54). Studi tentang lingkungan ini telah dilakukan sepanjang sejarah sebagaimana tertulis dalam buku tarian Thailand selama pemerintahan Raja Rama I (1782-1809). Gerakan ini bermula sejak periode Ayutthaya (1350-1767) dan tercatat sebagai bukti tertua. Seluruhnya ada 66 gerakan dalam tari klasik Thailand (Dhamrongrachanuphap, 2003: 58-61). Gerakan-gerakan tersebut adalah bukti sejarah dan merupakan gerakan yang lengkap yang menjadi dasar struktur gerak tari klasik Thailand.

Struktur tari klasik Thailand memiliki sistem saraf yang terletak di bagian tengah tubuh dan berfungsi untuk menjaga keseimbangan dan mengontrol otot-otot untuk bergerak. Selain itu, gerakan tari klasik Thailand penekanannya terletak pada semua 


\section{JOGED}

ISSN: $1858-3989$

gerakan dari setiap bagian tubuh dari awal hingga akhir proses (Somporn Furaj, 2011: 71).

Setiap saat gerakan tari klasik Thailand membutuhkan transmisi dari semua energi untuk membuatnya jelas dan indah. Gerakan ini mempengaruhi penggunaan napas saat bergerak yang digunakan hanya sedikit dari gerakan total penari. Penulis mewawancarai enam penari dari Jurusan Tari Klasik Thailand di Universitas Srinakharinwirot, Thailand. Penari yang diwawacara terdiri dari enam penari. Tiga penari perempuan yang disebut ตัวนาง (TuaNang) dan tiga penari laki-laki yang disebut ตัวพระ (TuaPhrah). Wawancara terfokus pada tingkat pernapasan atau Respiratory rate (sering ditulis sebagai $\mathrm{RR}$ atau $\mathrm{R}$ ) untuk menangkap laju pernapasan dalam satu menit, yaitu satu dari empat tanda vital yang digunakan untuk menunjukkan normal tidaknya tubuh, mencakup emosi, mental, atau penyakit dari berbagai organ. Tingkat pernapasan orang dewasa biasanya 12-18 kali per menit (Phuangthong Kraiphibun, 2013: Online)

Berdasarkan wawancara pengukur laju respirasi selama gerakan tubuh dalam tari klasik Thailand dari enam penari dari total 10 kali pengukuran ditemukan nilai rata-rata sebagai berikut: gaya karakter perempuan disebut ตัวนาง (TuaNang) rata-rata 9 kali per menit dan gaya karakter laki-laki disebut ตัวพระ (TuaPhrah) rata-rata 7 kali per menit (2019: wawancara). Menurut wawancara itu, ada indikasi pergerakan gaya tari klasik Thailand hanya sedikit menggunakan napas supaya menjaga keseimbangan tubuh bagi gerakan anggun khas dan unik tari Thailand yang mengutamakan keseimbangan. Ditemukan dalam beberapa gerakan seperti รำส่าย (Gerak Ramsai), ชักแป้งผักหน้า (Gerak Chackpengpadna) atau gerakan mengangkat kaki ke belakang nyaris tidak menggunakan napas saat bergerak. Ini berarti napas bukanlah komponen dari struktur inti yang sangat penting untuk gerakan tersebut. Napas hanya merupakan bagian dari gerakan tubuh. Tari klasik Thailand memerlukan tubuh dalam semua proporsi geraknya.

Kealamiahan gerakan fisik dalam sifat kemanusiaan terbatas, akibatnya energi alami dalam tubuh seorang penari juga terbatas. Padahal, gerakan tubuh dalam gaya tari klasik Thailand membutuhkan energi dalam semua proporsi gerakan. Dalam kaitan ini, napas, salah satu sumber energi alami yang mempengaruhi gerakan Tari Klasik Thailand telah lama diabaikan sebagai komponen latihan atau struktur gerakan. Hilangnya salah satu kekuataan sumber energi ini menuntut restorasi di dalam struktur tari klasik Thailand 
Mengembalikan energi yang hilang, yaitu energi dari napas yang terkait dengan pergerakan tubuh manusia penting bagi Tari Klasik Thailand. Hal ini mengarah pada kesadaran emosi kita dengan bernapas. Panjang dan dalamnya pernapasan dapat membantu kinerja fungsi paru-paru dan gerak tubuh. Hal yang juga membantu kualitas pengendalian mental. Fase ini membantu pelatih untuk memiliki pikiran yang tenang dan memahami kebenaran secara lebih alami. Proses latihan bernapas ini disebut 'Anapanasati' yang merupakan salah satu metode meditasi dan memiliki arti yang terfokus kepada napas ketika menghirup udara masuk dan menghembuskan udara ke luar. Ana atau Adsasah artinya bernapas masuk (breathing in), Apan atau Passanah artinya bernapas ke luar (breathing out), Sati artinya ingatan saat ini (mindfulness). Maka, Anapanasati artinya ingatan menarik napas masuk dan ke luar saat ini (mindfullness of breathing in and out). Salah satu kegiatan yang dapat membawa ketenangan pikiran. Artinya, dengan berlatih meditasi Anapanasati manusia bisa lebih mengetahui tubuhnya, merasakan emosi, dan memahami mentalnya dari dalam (Mitsuo Cowesko, 2010: 4). Praktik meditasi ini meliputi empat hal penting dalam proses pernapasan yang disebut 'empat-Satipatan'
(The Four Foundations of Mindfulness). Keempatnya terjadi dalam proses pernapasan Buddha. Keempat tahapan tersebut melatih kesadaran tubuh, kesadaran emosional, kesadaran mental, dan kesadaran Dhamma atau kebenaran yang terjadi dalam kehidupan. Semua ini adalah proses yang muncul melalui meditasi dengan napas Sang Buddha atau Anapanasati.

Latihan pernapasan Buddha ini mencakup kesadaran bernapas masuk dengan panjang, kesadaran bernapas ke luar dengan panjang, kesadaran bernapas masuk dengan pendek, kesadaran bernapas ke luar dengan pendek. Dengan melakukan irama bernapas yang alami, kita akan mengenali sentuhan setiap angin. Perasaan sentuhan ini akan berubah jika napas berubah, seperti semua hal di alam yang berubah seiring waktu. Dalam hal ini, kami menyaksikan angin melewati seluruh garis dari awal, tengah, dan akhir. Sementara mental terfokus pada angin, mental dan angin akan santai, sisa tubuh akan rileks juga. Karena napas adalah bagian dari tubuh. Kesadaran akan membantu kita melihat bahwa napas dan tubuh tidak sepenuhnya terpisah (Kunarattana Mahathera, diterjemahkan oleh Naiyana Nakwatcharat, 2013: 26-28). Metode bernapas di atas mengarah pada terjadinya empat hal penting dalam Satipatan (The Four 
JOGED

ISSN: $1858-3989$

Foundations of Mindfulness) yang terjadi melalui kesadaran. Metode bernapas ini dikenal sebagai Anapanasati yang lengkap yang membimbing ke arah meditasi.

\section{PEMBAHASAN}

\section{A. Tujuan Penciptaan}

Penciptaan karya seni ini memiliki tujuan untuk menemukan hubungan meditasi dalam bentuk pernapasan, yang disebut Anapanasati, dengan struktur gerakan tari klasik Thailand. Ini bisa mengarah pada salah satu bentuk atau metode gerakan tari Thailand yang berfokus pada penggunaan napas sebagai landasan struktur gerakan independen, alami, dan mengambil energi kekuatan dari dalam ke luar. Hal ini membuat gerakan tersebut tahan lama sehingga bisa bergerak dalam jangka waktu yang lebih lama dan merupakan gerakan yang tenang melalui meditasi yang alami, tanpa memaksa tubuh. Untuk menciptakan gerakan lain dalam tarian Thailand yang konsisten dengan doktrin Buddhisme, yang sadar akan jangkauannya saat ini dan alami melalui latihan dan kesadaran diri

\section{B. Konsep Penciptaan}

Hubungan Anapanasati atau napas Buddha dalam struktur gerakan tari klasik Thailand dengan kesadaran adalah konsep utama. Konsep ini menjelaskan hubungan prinsip-prinsip meditasi dalam bentuk Anapanasati dengan struktur gerak tari klasik Thailand. Tari ini merupakan salah satu bentuk percobaan pencipta dengan kembali ke proses untuk menunjukkan bahwa proses tidak kurang bernilai dari pada produksi. Ini dapat menyebabkan penemuan struktur dan elemen cara lain dalam bentuk tari klasik Thailand melalui proses pernapasan Anapanasati

\section{Teori dan Prinsip Penciptaan}

\section{Teori Pemrograman Gerak (Motor Programing Theory)}

Gerakan yang disebabkan oleh penghasil pola gerak merupakan gerakan berirama adalah pola berulang seperti pernapasan. Menurut teori ini, gerakan dapat terjadi dari penghasil pola irama (rhythmic pattern generator) tanpa kerja otak dan tidak perlu untuk aktuator dan sirkuit sensorik.

\section{Prinsip Anapanasati}

“Änāpānasati | Kayagatāsati.......I say that this is a cerlain body among the bodies, namely, in-breathing and out-breathing. That is why on that occasion a bhikkhu abides contemplating the body as a body..." "Bhikkhus, they do not partake of the deathless who do not partake of mindfulness directed to the body. They partake of the deathless who partake of mindfulness directed to the body." 
Bhikkhus, they have not pursued the deathless who have not pursued mindfulness directed to the body. They have pursued the deathless who have pursued mindfulness directed to the body. "Bhikkhus, they are heedless about the deathless who are heedless about mindfulness directed to the body. They are not heedless about the deathless who are not heedless about mindfutness directed to the body." (Bhikkhu nanamoli and bhikkhu (trans), 1995 : ISBN 978-08671710720)

Proses pelatihan bernapas yang disebut 'Anapanasati' yang merupakan salah satu metode meditasi dan memiliki arti fokus kepada napas ketika menghirup udara masuk dan menghembuskan udara ke luar. (mindfullness of breathing in and out). Salah satu kegiatan yang dapat membawa ketenangan pikiran. Artinya, dengan berlatih meditasi Anapanasati manusia bisa lebih mengetahui tubuhnya, merasakan emosi, dan memahami mentalnya dari dalam.

Berlatih melalui napas dalam bentuk Buddha adalah kesadaran bernapas masuk sedang panjang, kesadaran bernapas ke luar sedang panjang, kesadaran bernapas masuk sedang pendek, kesadaran bernapas ke luar sedang pendek. Ketika kita menyaksikan irama napas yang alami, kita akan mengenali sentuhan setiap angin. Perasaan sentuhan ini akan berubah jika napas berubah, seperti semua hal di alam yang telah berubah seiring waktu. Dalam hal ini, kita menyaksikan angin melewati seluruh garis dari awal, tengah, dan akhir. Sementara mental terfokus pada angin, mental dan angin akan santai, sisa tubuh akan rileks juga. Karena napas adalah bagian dari tubuh. Kesadaran akan membantu kita melihat bahwa napas dan tubuh tidak sepenuhnya terpisah.

Metode memperhatikan napas, itu mengarah pada terjadinya empat hal penting dalam empat-Satipatan (The Four Foundations of Mindfulness) adalah melatih kesadaran tubuh, kesadaran emosi, kesadaran mental, dan kesadaran Dhamma atau kebenaran yang terjadi dan dialami dalam kehidupan. EmpatSatipatan ini akan terjadi melalui kesadaran dengan memperhatikan napas bisa dianggap sebagai Anapanasati yang lengkap dan membimbing ke arah meditasi.

\section{Tari Klasik Thailand}

Struktur tari klasik Thailand memiliki sistem saraf yang mengontrol otot-otot untuk bergerak yang terletak di bagian tengah tubuh berfungsi untuk menjaga keseimbangan. Selain itu, gerakan tari klasik Thailand penekanannya pada semua gerakan setiap bagian tubuh dari awal hingga akhir proses. Setiap saat dalam gerakan tari klasik Thailand akan membutuhkan transmisi semua energi untuk membuat gerakannya jelas dan indah. Gerakan ini memengaruhi penggunaan napas saat 
bergerak yang digunakan hanya sedikit dari gerakan total penari

Penciptaan karya tari tentang hubungan Anapanasati atau napas Buddha dalam struktur gerakan tari klasik Thailand dengan kesadaran dari masalah gerakan tari klasik Thailand yang hanya menggunakan sedikit pernapasan, karena itu menggunakan metode meditasi dalam bentuk Anapanasati (napas Buddha) sebagai teori utama dan didukung oleh Teori Pemrograman Motorik dari anatomi untuk menemukan hubungan gerakan tari klasik Thailand yang penting dalam gerakan untuk bernapas para penari. Menghasilkan konsentrasi dalam kesadaran dan pemahaman tentang alam melalui ekspresi diri dengan hubungan menurut kerangka kerja konseptual sebagai berikut:
Gambar 1 kerangka kerja konseptual Sumber Potchanan Pantham

\section{B. Langkah Penciptaan}

Peneliti telah menentukan prosedur dan proses berikut,

1.Langkah 1 Persiapan penelitian dan persiapan kreatif.

a. Studi dokumen, teks dan penelitian terkait untuk digunakan sebagai informasi dasar dalam penelitian dan pembuatan

b. Wawancara dengan penari dari Jurusan Tari Klasik Thailand di Universitas Srinakharinwirot, Thailand. Terdiri dari enam orang penari yang diwawancarai dan dibagi menjadi tiga penari dengan menggunakan gaya karekter perempuan yang disebut ตัวนาง (TuaNang) kemudian tiga penari lainnya gaya

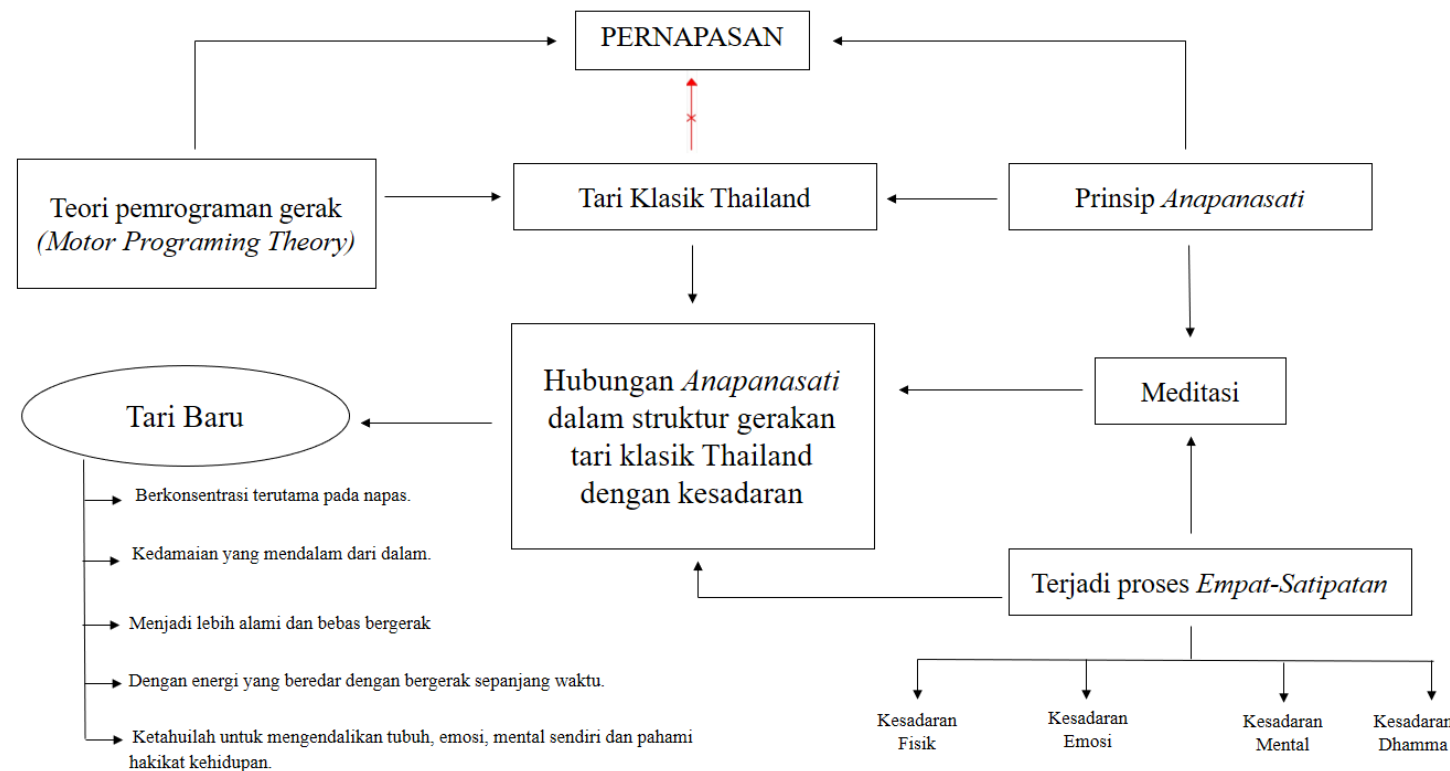


karekter laki-laki yang disebut ตัวพระ

(TuaPhrah). Wawancara ini menggunakan prinsip tingkat pernapasan atau Respiratory rate, total 10 kali. Dengan melihat tingkat respirasi

rata-rata penari profesional selama pergerakan gaya tarian klasik Thailand untuk membawa hasilnya menjadi informasi awal dalam desain dan penciptaan karya tari.

2. Langkah 2 Gerakan eksperimental dengan cara baru dari prinsip-prinsip yang diambil dari teori.

a. Percobaan pertama dalam pertunjukan Anapanasati.

b. Percobaan kedua dalam pertunjukan Anapanasati II.

c. Percobaan struktur gerakan tari klasik Thailand dengan menggunakan tari 'แม่บทใหญ่ (Mei-Bod-Yai)' (tari asli klasik Thailand) menjadi studi kasus.

d. Percobaan gerakan manusia dalam Teori Pemrograman Motor.

e. Percobaan hubungan gerakan tari klasik Thailand dengan prinsip Anapansaati untuk mencari gerakan baru.

f. Melakukan latihan dengan penari dari Indonesia yang dasar geraknya adalah gaya tari Jawa Yogyakarta (Karena ada beberapa struktur gerakan yang mirip dengan tarian klasik Thailand) untuk menguji gerakan baru yang telah diuji.

\section{Langkah 3 Pertunjukan Kreatif}

a. Menentukan format pertunjukan, gaya musik, menentukan kualifikasi penari, kostum, properti, pola pencahayaan, dan lokasinya.

b. Memilih penari yang cocok dengan karya kreatif ini.

c. Penciptaan musik untuk pertunjukan.

d. Penciptaan kostum untuk pertunjukan.

e. Penciptaan properti untuk pertunjukan.

f. Latihan dengan penari dan terus meningkatkan kinerja.

g. Tetapkan tanggal untuk pertunjukan dan membentuk panitia untuk membantu jalannya pertunjukan.

h. Hubungi lokasi yang digunakan untuk pertunjukan.

i. Pertunjukan

4. Langkah 4 Ringkasan hasil penelitian dan membuat buku yang lengkap.

\section{Sintesis Penciptaan}

Proses penciptaan karya tari pada hubungan Anapanasati atau napas Buddha dalam struktur gerakan tari klasik Thailand dengan kesadaran. Eksperimentasi tentang hubungan napas gaya Anapanasati dalam 


\section{JOGED}

ISSN: $1858-3989$
Potchanan Pantham A-Na(d) tayaSati Hubungan Anapanasati (Nafas Buddha) di dalam Struktur Tari Klasik Thailand

struktur gerakan tari klasik Thailand, sebagai

berikut:

1. Pertunjukan Pertama, judal

'Anapanasati' tahun ajaran 1/2017.
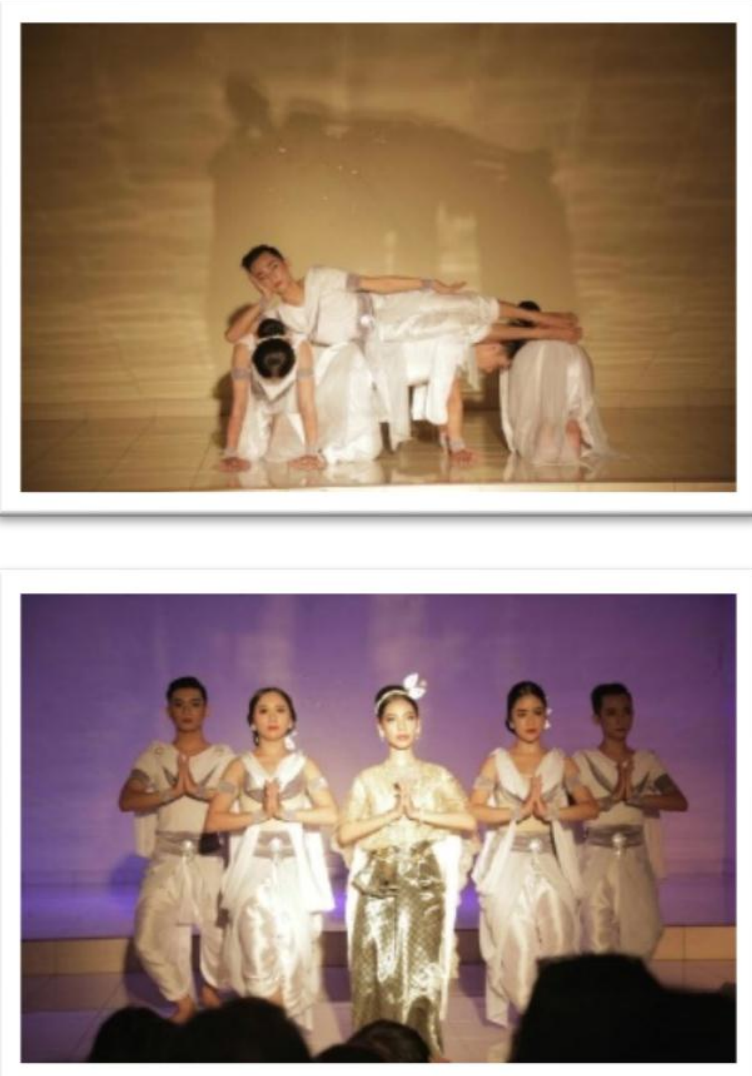

Gambar 2. Anapanasati tahun ajaran 1/2017. Foto: Moch Rizky

\section{Ringkasan Hasil dari Pertunjukan Pertama}

Pertunjukan Anapanasati ini menemukan hubungan penari yang lebih tenang dan berkonsentrasi saat menari dengan metode pernapasan dari prinsip Anapanasati melalui tari klasik Thailand dan kesadaran kepada asal dari empat-Satipatan (The Four Foundations of Mindfulness).

3. Pertunjukan Kedua, judul ‘Anapanasati II tahun ajaran 2/2017
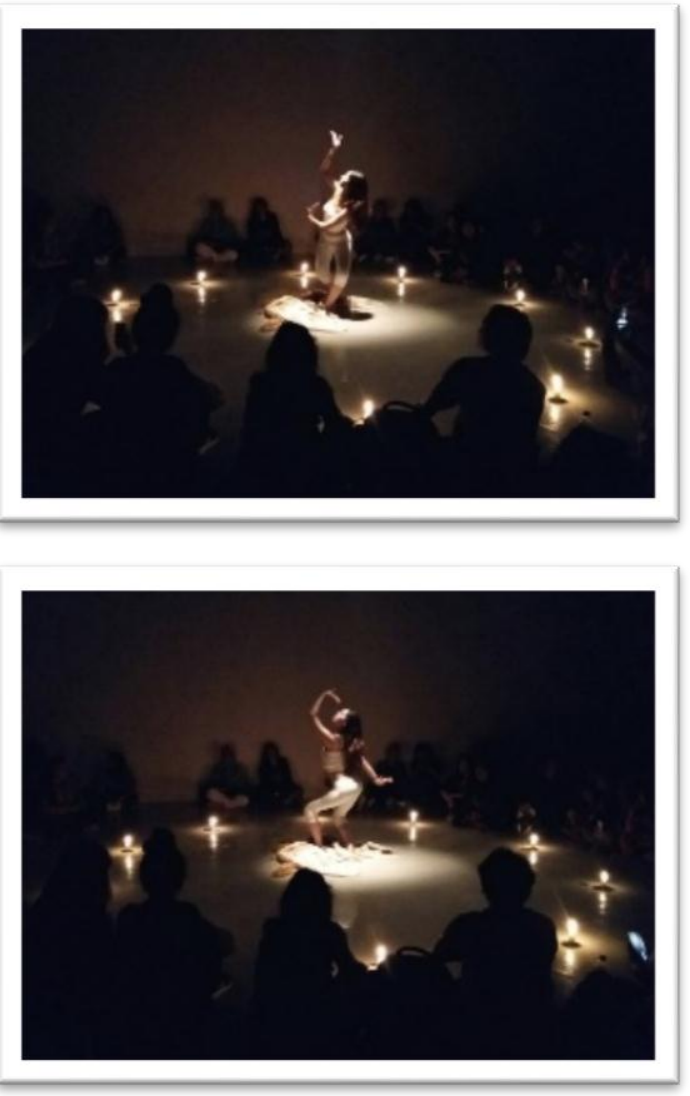

Gambar 3. Anapanasati II tahun ajaran 2/2017 Foto: Bangkit Sanjaya

Berdasarkan percobaan, sepuluh postur utama dari gerakan tarian Thailand asli yang disebut 'แม่บทใหญ่ (Mei-Bod-Yai)' adalah sebagai berikut: 


\begin{tabular}{|c|c|c|c|}
\hline Nama gerak & Gerak asli & Gerak baru & Penjelasan \\
\hline $\begin{array}{l}\text { ท่าผาลาเพียงไหล } \\
\text { (Phalapenglai) }\end{array}$ & & & $\begin{array}{l}\text { Gerak satu tangan ke atas, satu tangan } \\
\text { ke bawah dari proses mengikuti } \\
\text { pernapasan cara Anapanasati } \\
\text { membuat gerak tubuh berubah dari } \\
\text { gerak asli. }\end{array}$ \\
\hline $\begin{array}{l}\text { ท่าจันทร์ทรงกลด } \\
\text { (Jansongklot) }\end{array}$ & & & $\begin{array}{l}\text { Gerak dua tangan ke samping tubuh } \\
\text { dari proses mengikuti pernapasan cara } \\
\text { Anapanasati membuat gerak tubuh } \\
\text { berubah dari gerak asli. }\end{array}$ \\
\hline $\begin{array}{l}\text { ท่าชักซอสามสาย } \\
\text { (Chaksawsamsai) }\end{array}$ & & & $\begin{array}{l}\text { Gerak satu tangan ke atas kepala, satu } \\
\text { tangan ke samping pinggul dari proses } \\
\text { mengikuti pernapasan cara } \\
\text { Anapanasati membuat gerak tubuh } \\
\text { berubah dari gerak asli. }\end{array}$ \\
\hline Nama gerak & Gerak asli & Gerak baru & Penjelasan \\
\hline $\begin{array}{l}\text { ท่านางกล่อมตัว } \\
\text { (Nangklomtua) }\end{array}$ & & & $\begin{array}{l}\text { Gerak dua tangan di depan perut dari } \\
\text { proses mengikuti pernapasan cara } \\
\text { Anapanasati membuat gerak tubuh } \\
\text { berubah dari gerak asli. }\end{array}$ \\
\hline $\begin{array}{l}\text { ท่าชักแป้งผัดหน้า } \\
\text { (Chakpengpadna) }\end{array}$ & & & $\begin{array}{l}\text { Gerak satu tangan ke kepala, satu } \\
\text { tangan di depan bibir dari proses } \\
\text { mengikuti pernapasan cara } \\
\text { Anapanasati membuat gerak tubuh } \\
\text { berubah dari gerak asli. }\end{array}$ \\
\hline
\end{tabular}




\section{JOGED}

ISSN: 1858-3989
Potchanan Pantham A-Na(d) tayaSati Hubungan Anapanasati (Nafas Buddha) di dalam Struktur Tari Klasik Thailand

\begin{tabular}{|l|l|l|}
\hline $\begin{array}{l}\text { ท่าบัวชูสก } \\
\text { (Buachufak) }\end{array}$ & $\begin{array}{l}\text { Gerak satu tangan ke atas kepala, satu } \\
\text { tangan di depan perut dari proses } \\
\text { mengikuti pernapasan cara } \\
\text { Anapanasati membuat gerak tubuh } \\
\text { berubah dari gerak asli. }\end{array}$ \\
\hline $\begin{array}{l}\text { ท่าช้างหว่านหญ้า } \\
\text { (Changwanya })\end{array}$ & $\begin{array}{l}\text { Gerak satu tangan ke atas kepala, satu } \\
\text { tangan ke samping tubuh dari proses } \\
\text { mengikuti pernapasan cara } \\
\text { Anapanasati membuat gerak tubuh } \\
\text { berubah dari gerak asli. }\end{array}$ \\
\hline $\begin{array}{l}\text { ท่ายูงฟ้อนฟ้อนหาง } \\
\text { (Yungfonhang) }\end{array}$ & $\begin{array}{l}\text { Gerak dua tangan ke belakang tubuh } \\
\text { dari proses mengikuti pernapasan cara } \\
\text { Anapanasati membuat gerak tubuh } \\
\text { berubah dari gerak asli. }\end{array}$ \\
\hline
\end{tabular}

\begin{tabular}{|l|l|l|l|}
\hline \multicolumn{1}{|c|}{ Nama gerak } & Gerak asli & Gerak baru & \multicolumn{1}{c|}{ Penjelasan } \\
\hline $\begin{array}{l}\text { ท่าขี่ม้าตีคลี } \\
\text { (Kimatikle })\end{array}$ & $\begin{array}{l}\text { Gerak satu tangan ke atas kepala, satu } \\
\text { tangan ke samping tubuh dari proses } \\
\text { mengikuti pernapasan cara } \\
\text { Anapanasati membuat gerak tubuh } \\
\text { berubah dari gerak asli. }\end{array}$ \\
\hline $\begin{array}{l}\text { ท่ากวัดเกล้า } \\
\text { (Kawadklaw) }\end{array}$ & & $\begin{array}{l}\text { Gerak dua tangan ke atas kepala dari } \\
\text { proses mengikuti pernapasan cara } \\
\text { Anapanasati membuat gerak tubuh } \\
\text { berubah dari gerak asli. }\end{array}$ \\
\hline
\end{tabular}




\section{Ringkasan Hasil dari Pertunjukan Kedua}

Pertunjukan Anapanasati II ini berhasil menemukan hubungan gerakan tari klasik Thailand melalui meditasi gaya pernapasan yang membuat pergerakan tubuh para penari lebih tenang dan alami, menemukan beberapa energi dalam gerakan yang tidak pernah berakhir.

\section{PENUTUP}

Penulis melakukan eksperimentasi tentanghubungan napas gaya Anapanasati dalam struktur gerakan tari klasik Thailand beberapa kali. Dua kali diakhiri dengan pertunjukan. Hal-hal baru yang timbul dari percobaan tersebut, sebagai berikut:

1. Kemampuan berkonsentrasi terutama pada napas.

2. Menemukan rasa kedamaian yang mendalam dari dalam diri.

3. Menjadi lebih alami dan bebas dalam bergerak

4. Mampu mengatur energi yang beredar untuk bergerak sepanjang waktu
5. Mampu mengendalikan tubuh, emosi, mental sendiri dan memahami hakikat kehidupan.

Penciptaan hubungan Anapanasati (napas Buddha) dalam struktur gerakan tari klasik Thailand (A-na(d)tayasati) dengan kesadaran dengan prinsip meditasi dalam bentuk Anapanasati yang didukung oleh Teori Pemrograman Motor dari prinsip anatomi. Hal ini menemukan hubungan struktur gerakan tari klasik Thailand yang penting dalam gerakan dengan napas para penari. Menghasilkan konsentrasi kesadaran dan pemahaman tentang alam melalui gerakan diri. Karya ini menuju ke salah satu bentuk atau metode gerakan tari Thailand yang berfokus pada hal yang penting pada penggunaan napas sebagai dasar penting dari struktur gerakan independen, alami, dan mendapat energi yang kuat dari dalam ke luar. Gerakan seperti itu menjadi lebih tahan lama, yaitu bisa bergerak dalam periode waktu yang lebih lama dan merupakan gerakan yang tenang melalui meditasi yang alami tanpa memaksa tubuh atau menekan alam tubuh dengan cara apapun. Untuk penyebab cara bentuk gerakan lain dalam industri tarian Thailand yang konsisten dengan ajaran agama Buddha yang sadar akan kehadiran sendiri dan akses ke alam melalui latihan dan kesadaran 
diri dengan memahami struktur tari klasik Thailand secara mendalam dalam proses dengan menggunakan napas untuk mengendalikan gerakan tubuh. Konsentrasi yang terjadi akan memiliki energi yang dikirim untuk mengendalikan berbagai gerakan tubuh yang berbeda, bergantung pada latihan masingmasing. Termasuk memahami dan mengakses sifat mereka sendiri dengan waktu dan kesiapan yang berbeda juga, tetapi akan dapat belajar dan mengetahui lebih banyak tentang dirinya melalui kinerja pertunjukan tersebut. Hal ini memiliki efek yang baik untuk mengendalikan tubuh, emosi, dan pikiran dengan menyadari sifat yang dekat dan menerima perubahan yang terjadi setiap saat. Seolah bergerak dari satu posisi ke posisi lain dengan bebas, kesadaran hanya posisi yang akan terjadi saat ini yang sebanding dengan segala sesuatu dalam hidup yang terlihat seperti ini. Jadi, berada bersama masa kini adalah konsentrasi kesadaran yang terkuat.
Cowesko, Mitsuo. 2010. Anapanasati cara

bahagia. Bangkok : Sengdedperkdek.

Dhamrongrachanuphap HRH Prince. 2003.

Cerita Tarian. Bangkok: Matichon.

Furaj, Somporn. 2011. Mime The Performance and The Movement. Bangkok:

Thammasat.

Jaingwiwattanapron, Parichad. 2006. Pichet

Klunchun, The Way of Thai Dance.

Bangkok: Kidpaisan and Subply.

Kunarattana Mahathera, Bhiksu. 2013. The

Four Foundations of Mindfulness in plain English. diterjemahkan oleh Naiyana

Nakwatcharat. Bangkok: Komol

Kiemtong Foundation.

Phuangthong Kraiphibun, Honorary Professor Female Doctor. (2013). Respiratory rate. Macropedia Didapat dari:

http:/haamor.com/th/อัตราการหายใจ,

1 Febuari 2019.

Pudtawajana Staban. 2015. Pudtawajana

Dhamma tentang Anapanasati.

Prathumtani: Munlaniti Pudtakote.

\section{DAFTAR ACUAN}

Bunsinsuk, Rampa dan Prayord. 2004. Motor

System. Bangkok: Srinakharinwirot. 